\title{
THE ACTIVATION OF FORMS OF HIGHER EDUCATION AND THE COMPETENCE OF A UNIVERSITY TEACHER
}

\author{
MICHAELA TURECKIOVA, JANA MARIE ŠAFRÁNKOVÁ
}

\begin{abstract}
:
The article is based on long-term knowledge and partial researches of the authors focused on reflection of students and teachers and on various teaching methods used for activation of university students mostly in the fields of study focused on management and personnel management. The aim of the paper is to reflect the competences of the university teacher necessary for the realization of various forms of teaching, their comparison with students' opinions and attitudes and to reflect on changes in attitudes to teaching lectures, seminars and exercises so as .Using a questionnaire survey and controlled interviews at the Faculty of Education, Charles University, School Management Centre (since 2018 Department of Andragogy and Education Management), a sample of 325 students in combined study. data were continuously collected in 2015-2018, Masaryk Institute of Advanced Studies, CTU in Prague, 350 full-time students. Nowadays it is necessary with the generation change of students, with informatisation and digitization, the influence of society 4.0 to change the way of teaching to suit the attitudes and thinking of the current generation of students and to enable the transfer of knowledge and skills and their fixation. The main approaches are the activation method of teaching, linked to the group, respectively. teamwork. The relevance of the findings is tied to the study of differentiation between full-time and full-time students in relation to the age cohort.
\end{abstract}

\section{Keywords:}

Competence, university teacher, form of higher education, activisation forms in teaching

JEL Classification: 121, 123, J24

\section{Authors:}

MICHAELA TURECKIOVA, Faculty of Education, Charles University, Department of Andragogy and Educational Management, Czech Republic, Email: michaela.tureckiova@pedf.cuni.cz JANA MARIE ŠAFRÁNKOVÁ, Faculty of Education, Charles University, Department of Andragogy and Educational Management, Czech Republic, Email: janamarie.safrankova@pedf.cuni.cz

\section{Citation:}

MICHAELA TURECKIOVA, JANA MARIE ŠAFRÁNKOVÁ (2019). The activation of forms of higher education and the competence of a university teacher. International Journal of Teaching and Education, Vol. VII(2), pp. 86-96., 10.20472/TE.2019.7.2.007 


\section{Introduction}

The article is based on long-term knowledge and partial researches of the authors focused on reflection of students and teachers and on various teaching methods used for activation of university students mostly in the fields of study focused on management and personnel management. It focuses on two perspectives on this issue, namely the connection of the competences of the university teacher with the requirements for activating teaching methods and the students' opinions on the competences needed for the good job market after graduation (Safrankova, Sikyr 2018).

A university teacher (currently referred to as an academic) is a university-educated professional, a college employee, and an academic bearer. This refers to "the qualified activity of a teacher in a higher education institution. The performance of this profession is associated with a certain social status, ... translates into ... a social role as a set of expectations linked to the specific manifestations of their bearers" (Linhart, online). According to Vašutová (2002), the academic profession has a dynamic character, it takes into account the process of professionalization and the main stages of this process are defined by legislation.

The above-mentioned characteristics are confirmed by the current wording of Act No. 111/1998 Coll. (Higher Education Act). The term "university teacher" is not used in it; In Section 70 (1) it is stated that: "Academic staff are those professors, associate professors, associate professors, lecturers, assistants, lecturers and researchers, researchers and researchers who are employees of the university performing their employment according to the agreed type both academic and creative work. Academics are obliged to respect the good name of the university. " It is clear that each academic performs different types of work activities, of which pedagogical activity is given first. At the same time, however, it follows from the wording of the law that pedagogical activity is not the only activity that an academic worker is engaged in. Its scope is broader. In addition, it may be inferred that for their own pedagogical activity, "they probably do not need to be well prepared nowadays, because no legal regulation deals with this fact today" (Linhart, online).

The concept of the academic profession is thus not only dynamic. At the same time, it is comprehensive in terms of the roles and required competences of the academic employee, with an emphasis on the quality of the activities performed by him / her. Linhart (online) emphasizes the importance of the professionalism and the long-term nature of the academic process of professionalism, further stating that the professionalization process should include "not only the optimal selection of candidates for university professions, but also a comprehensive system of undergraduate and postgraduate university training "(ibid). This implies a requirement to focus on the training and development of academics at all stages of their careers. This area is also dealt with in the field of science and study discipline of higher education (for example, Vašutová, 2002, Slavík, M. et al. 2012).

One of the reasons to concentrate on the requirements for vocational training and especially the professional development of academic staff in teaching activities is the importance of their work in the university space and the transformation of this environment. For this reason, experts also strive to define models of desirable competencies of academic staff. These models more or less comprehensively cover the field of professionalization of academics not only in terms of career development in terms of academic achievement, but also in the 
importance of their work as university teachers and researchers in science, research, publishing and other creative activities. academics at various universities are involved.

Main reason to training of academic staff in teaching activities are activation methods in teaching. Activation methods in teaching at primary and secondary schools have been used for a long time; they are methods of method in which the activity is clearly visible to students, is both thought-based and manifests itself in behaviour and action. Activation methods also emphasize the individual work of students and their cooperation with the teacher, which leads to their higher participation in teaching. The primary goal of these methods is to transform passive students into learning learners who learn much more by direct experience than using one-sided traditional frontal teaching methods. (Kotrba, Lacina, 2007). Usually, discussions, learning games, project method, group work methods, experiential learning methods, etc. are called activation methods.

The current young net generation is characterized by the prevailing impatience, speed and often lack of concentration. Activation methods of teaching are very suitable for net generation. At universities, one of the options is the application of group work and project teaching adapted to the current requirements of didactic impact on students. In universities, activation methods are still used only partially, because they require quality and sophisticated teacher training. The seminars require a different type of university teacher training, teacher experience and a broader perspective, and since most of the exercises are conducted by young assistants or doctoral students, they lack long-term experience that would be used by the teacher.

Activation education in the basic definition is understood as a way of teaching when students are given a precisely formulated problem, respectively. the goal to be achieved, in a predetermined time, in a specified pair or group, the results must be evaluated and, if possible, practically usable. The topics of the tasks should be interesting enough to motivate the students themselves to the activity and the students themselves have a desire to penetrate the issue, search for information, sort, use and achieve the goals. (Kasova, Tomkova, Dvorakova, 2009)

Activation instruction enables students to understand and manage the course as a whole, including the links (causes and consequences) between activities. The limiting factor is again time-consuming, because the space for students' work is more reserved for the exercises. The principles of activation teaching implicitly involve working with key competencies and developing soft skills, such as applying different leadership styles, communication and negotiation skills, etc., and in connection with teamwork the possibility of personality formation in relation to responsibility and willingness take-over responsibility, tolerance, creativity, activity, persistence, ability to transmit and receive feedback, etc. (Kratochvílová, 2006). "Simulation methods evoke a playful character of a situation that is not confrontational, as in real life. Therefore, they make it easy for individuals to move freely, gain insight, and take a certain attitude without fear. At the same time, they lead from mere speaking to experiencing and acting" (Skalková J., 1999). Situation methods allow pupils to acquire skills, analyse and solve problems that represent different life situations. By situational methods we understand procedures for problem solving of model situations, which are based on real events and are typical or specific for a certain area of practice. This includes, for example, the resolution of various conflict situations. Solving models of real situations usually requires a comprehensive 
approach, assumes flexible use of productive thinking knowledge, mutual cooperation, etc. By solving marginal and conflict situations, we prepare pupils for real problem situations. (Skalkova J., 1999).

Other activation methods used are creativity of mind map, brainstorming discussion, but also systematic solution of case studies or analysis of a specific problem.

Approaches to academic staff teaching methods is going through academic staff competencies. The notion of competence has appeared in the pedagogical sciences and in andragogy in the Czech Republic since the 1990s. According to Prücha and Veteška (2014), it includes concepts such as skill, ability and competence, the interconnection of which enables the competent performance of an individual (the holder of a set of competencies). "The concept of competence can therefore also be defined as one's unique ability to act successfully and further develop its potential based on an integrated set of own resources, in the specific context of various tasks and life situations, combined with the ability and willingness (motivation) to make decisions Responsibility." (Veteška, Tureckiová, 2008, p. 27) Competence as an output category (learning outcome) is" the result of a long-term, purposeful and thoughtful development of an individual's innate dispositions, knowledge, abilities and attitudes "(Linhart, 2002, cit. (Linhart, online).

The author also defines and characterizes the types of competencies of an academic worker. In her article (Linhart, online) she describes the following types of competencies: The professional competence of an academic is defined as "a set of individual competences of a different nature, which together create an image of the profession and the professionalism of a peculiar personality of an academic" (ibid). The author of the model states that it is difficult to clearly define the set, however, it presents the following structure of professional competence: professional competence, scientific-research competence, managerial competence, counselling competence, psychodidactic competence, psychosocial competence (ibid).

The above-mentioned overview of individual components (components or subsystems, or modules) of the complex professional competence then reflects not only the complexity of the role and the diversity of requirements for the academic staff's competences. At the same time, especially in the psychodidactic and psychosocial competences it refers to the requirements for the ability of the university teacher and his knowledge and skills (among other things) to choose "the appropriate ratio of teaching forms, to carry out their successful forms, Linhart, online). Thus, the competence model created by Linhart and briefly summarized in the previous section is also directly related to the focus of this study.

We would like to draw attention to another competency model, which defines a similar structure of competence of an academic employee. The model is identified as a model of competencies of university / university teachers (Blaško, Blašková, Kucharčíková, 2014) and contains the following overview of competency types: professional / professional - added authors, 463-465). The advantage of this model is both the description (determination) of competence in relation to its bearer and the introduction of behaviour indicators (description of positive and negative behaviours).

According to the abovementioned list of competencies, the authors consider the professional competence as one of the partial ones and describe its bearer as a person "qualified and recognized as a specialist in the field taught and dedicated to research, ..., an expert who combines theoretical knowledge with practical knowledge and experience ... who knows how 
to apply principles, methods ... and finds connections between them "(Blaško, Blašková, Kucharčíková, 2014, p. 463). Therefore, we also present in the overview of competences according to the model of competencies of the university teacher the possible definition of the just defined competence not only as a professional, but in the alternative as a professional (it concerns the content and methods of the university teacher activities in subjects of his / her professional.

For the purposes of this study, it is especially important to specify the educational competence. Therefore, in accordance with the authors of the cited model, this is further characterized not only by its description, but also by indicators of behaviour (positive and negative, ie coping vs. non-coping of competence / role). For clarity, competence is defined graphically (Table 1).

Table 1 Characteristics of educational competence

\section{Educational competence}

"... excellent teacher; can define the key terms and elements of each topic and explain it to students comprehensively; it uses and skilfully combines different educational methods and practices, always related to the curriculum it teaches; utilizes both formative and summative assessment of knowledge, skills and maintains objectivity and impartiality towards students. "

Behaviour indicators

Positive $\quad$ Negative

In relation to students, he acts as a facilitator and an active factor in their development. It regulates the content, educational methods and scope of the curriculum of the students' intellectual capacity and their ability to absorb the curriculum. He continuously cultivates his teaching skills.

Source: Blaško, Blašková, Kucharčíková, 2014, p. 463 (authors form) 
There was great interest in educational competencies in the early 21 st century because of the widespread belief that the quality of teaching makes a significant difference to school and student outcomes (Lorencova, 2017).

\section{Goal and Method}

The aim of papers based on summarizing the results of the authors' survey on the analyses of competencies and reflection of teaching methods competencies by students. The goal of the paper is to reflect the competences of the university teacher necessary for the realization of various forms of teaching, their comparison with students' opinions and attitudes and to reflect on changes in attitudes to teaching lectures, seminars and exercises so that.

The research questions is: What university teachers'competencies are more important for students' competencies development?

The data were obtained by means of a questionnaire survey at the Faculty of Education, Charles University, Department of Andragogy and Education Management (Centre for School Management until 2018. The sample consisted of 325 students of combined study of School Management and Education Management). 350 full-time students were invited to attend fulltime studies at the Masaryk Institute of Advanced Studies, CTU in Prague.

There are 675 students in the sample, out of which 350 studied full-time study (CTU, MÚVS Economics and Enterprise Management), ie 52\% of the sample, and 325 students in combined study, Bachelor's and Master's degree program combined form (School Management and Education Management) ), Faculty of Education, Charles University, ie 48\% of the total sample. In the sample there are $27 \%$ men, $73 \%$ women, according to the year of study - 108 (16\%) first year; $175(26 \%)$ second year; $140(20 \%)$ third year of bachelor's degree; 160 (24\%) masters 1. year.; 92 (14\%) 2nd year. Numbers of respondents by data collection in individual years 2016-20; 2017-230; 2018-225. at both universities they are students of managerial and economic fields of study.

\section{Results and Discussion}

The above-mentioned competences are also related to the requirements for competences acquired in education, which are addressed by European and world organizations. As an example, the training needs for phase 4 'modernization and society 4.0 are given.

Training needs for the 4th phase of modernization (in teaching):

Basic knowledge development by teaching

- Literacy

- Mathematics"

- Science

- Information and communication technologies

- Finance

- Multiculturalism and civic awareness 
Know how development by teaching

- Problem solving

- Critical spirit

- Creativity

- Communication

- Cooperation

Personality development by teaching

- Initiative

- Durability

- Customization

- The art of leading

- Social and cultural compassion (Davos 2017)

Students consider the ability to communicate with people as the most important (between $79 \%$ and $67 \%$ of consent, actively solve problems related to the work performed (answer to this statement yes in the range of 76 to $71 \%)$ ) ), the fourth place has the long-term ability of teamwork (57-51\% consent), the fifth place the ability to use new knowledge (55$53 \%$ consent), the sixth ability to adapt to the requirements of the organization $(40-35 \%$ consent) and last but not least the ability to bear the risk (consent ranging from 37 to $34 \%)$.

Table 2 Students' opinions on important competences for the labour market (students 2016, 2017,2018 in \%)

\begin{tabular}{|l|l|l|l|}
\hline Competence & Students 2016 & Students 2017 & Students 2018 \\
\hline $\begin{array}{l}\text { To communicate with } \\
\text { people }\end{array}$ & 79 & 67 & 73 \\
\hline Solve problems & 76 & 71 & 72 \\
\hline $\begin{array}{l}\text { Applications of } \\
\text { knowledge to work }\end{array}$ & 57 & 63 & 59 \\
\hline Ability to teamwork & 57 & 51 & 53 \\
\hline $\begin{array}{l}\text { To use new } \\
\text { knowledge }\end{array}$ & 55 & 53 & 54 \\
\hline $\begin{array}{l}\text { To adapt to the } \\
\text { requirements of the } \\
\text { organization }\end{array}$ & 40 & 37 & 35 \\
\hline To bear the risk & 36 & 37 & 36 \\
\hline
\end{tabular}

Source: Author results

Table 3 Students' opinions on the effectiveness of forms of teaching - used to gain knowledge (students 2016, 2017, 2018 in \%)

\begin{tabular}{|l|l|l|l|}
\hline $\begin{array}{l}\text { Methods of } \\
\text { teaching }\end{array}$ & Suitable & Partially suitable & Non suitable \\
\hline Lectures & 30 & 45 & 25 \\
\hline
\end{tabular}




\begin{tabular}{|l|l|l|l|}
\hline $\begin{array}{l}\text { Lectures with } \\
\text { discussion }\end{array}$ & 40 & 45 & 15 \\
\hline Seminars & 74 & 20 & 6 \\
\hline Seminar work work in the & 59 & 32 & 19 \\
\hline $\begin{array}{l}\text { Group } \\
\text { classroom }\end{array}$ & 30 & 12 \\
\hline Electronic resources & 48 & 46 & 6 \\
\hline Diploma thesis & 71 & 23 & 6 \\
\hline
\end{tabular}

Source: Author results

The asked university students are still mainly led to individual work and in practice they face adaptation problems. There is still a negative assessment of forms of teaching that are just passive acceptance. The results of the survey show the importance of exercises and seminars, especially in terms of the possibility of individual approach of the teacher and practicing the subject matter. In terms of practice and preparation for the future profession, students best evaluate those forms of teaching in which they can participate to a greater extent by their own activities, ie. bachelor and master theses. The direction of teaching is to some extent related to skills that are important in practice. The development of the necessary skills of students can subsequently improve their working ability. From the above knowledge it can be hypothetically deduced that in practice it is not a matter of adapting to the given situation of the company, resp. organization rather than the ability to solve problems in good communication with people. The acquired knowledge shows that the students basically agree, they are united without any significant difference in the influence of the studied faculty.

Around 2000, when Generation Y began to enter higher education (born from the 1980s to the mid-1990s), students began to change their approach to teaching. The high motivation to study and acquires knowledge was gradually exchanged for the study with the least effort and failure to fulfil the assigned tasks. They spend most of their time on the Internet, even the time they should spend learning and embedding in practice. It is very difficult to tear them away from your computer, tablet, smartphone and other media. They are very difficult to attract and their knowledge is very fragmented. Generation Z (born 1995-2010) is already starting to be studied at universities. ability to work with context, critical thinking, deeper and wider knowledge.

The results of the research clearly show that the active methods of teaching for students competencies development are one of the more important part of successful preparation of future universirty graduates for labour makte.

\section{Conclusion}

This paper summarizes the current results of the authors' research focused on reflection of university teachers competencies in teaching students'by methods of activisation. Firstly, the results confirm the main findings of earlier studies cited above and show some interesting tendencies in the students' analyses of active methods of teaching that should be well analysed and discussed. These tendencies lie in the fact that students are very motivated to 
learn and study by best practice examples, but in this connection, they complain of theoretical subjects with connections and practical applications. This satisfaction can increase the motivation of students to study.

Secondly the results show reflection on competencies seeing by students. Through questions, it was found that the following competencies were knowledge of communication skills. social working in teams, solving problems and conflicts.

The fourth industrial revolution is changing the needs of the labour market for the competences of students and graduates. Students should have a good chance of succeeding in the labour market because of the opportunity to gain flexibility, knowledge, skills and abilities, but should change their attitude towards preparing for a future career.

New approaches in teaching - teamwork, context development, analysis. New possibilities for further research in the area of changing key competences, motivation and employability of university students, especially in the area of human resources management and diversity management in the management of various groups of workers. New approaches to the workforce in the management and human resources management for otherwise oriented generations.

Activation instruction enables students to understand and master the subject as a whole and to use the application of partial team management activities in group work, participates in the development of social competencies, enables formation of personality in relation to responsibility and willingness to take responsibility, tolerance, creativity, activity, endurance, and receive feedback. It aims to better consolidate the knowledge and skills acquired in management subjects. On the other hand, it places higher demands on academic staff and their pedagogical competences, it requires systematic preparation of activation methods for individual subjects. The direction of teaching is related to competencies that are important for successful self-assertion. Graduates most lack teamwork, people management and communication skills.

The scientific value of this paper is analyses of university teacher competencies towards active teaching methods in Czech Republic. 


\section{References}

Blaško, M., Blašková, R. \& A. Kucharčíková. (2014). Competences and Competence Model of University Teacher. Procedia - Social and Behavioral Sciences. 159 (2014), p. 457-467. https://doi.org/10.1016/j.sbspro.2014.12.407

Linhartová, D. (online). Profesionalizace akademické profese: Některé problémy. ( $P$ Professionalization of academic profession. Some problems) http://www.agris.cz/Content/files/main_files/61/139347/linh.pdf

Kašová, J., A. Tomková, M. Dvořáková. (2009) Učíme v projektech. (We teach in projects) 1. vyd. Praha: Portál.

Kotrba, T., Lacina, L. (2007) Praktické využití aktivizačních metod ve výuce. (Practical use of activation methods in education) Brno Barrister a Principal.

Kratochvílová, J. (2006) Teorie a praxe projektové výuky. (Theory and practice of project teaching) 1. Ed.. Brno: Masarykova univerzita.

Lorenzova J. (2017). Childhood through the lens of social pedagogy. International Journal of Social Sciences, Vol. VI(1), pp. 53-70. , DOI: 10.20472/SS2017.6.1.005

Průcha, J. \& Veteška, J. (2014). Andragogický slovník. (Andragogical Dictionary) 2. Ed.. Praha: Grada Publishing.

Skalková, J: (1999) Obecná didaktika. ( Gemneral didactics) Praha: ISV nakladatelství.

Slavík, M. a kol. (2012). Vysokoškolská pedagogika: Pro odborné vzdělávání (University Education: For Vocational Education). Praha: Grada Publishing.

Šafránková, J. M., \& Šikýř, M. (2018). Responsibilities and competencies in personnel management at Czech schools. Oeconomia Copernicana, 9(3), 529-543. doi:10.24136/oc.2018.027

Tureckiová, M. Veteška, J. (2008) Competences in education (Kompetence ve vzdělávání). Praha, Grada. ISBN 978-80-247-1770-8 
Vašutová, J. (2002). Strategie výuky ve vysokoškolském vzdělávání. (Teaching strategies in higher education). Praha: UK, Pedagogická fakulta.

Veteška, J. (2013) The role of qualifications and competences in initial and further education. Chowanna, tom 2 (41), pp. 179-191. ISSN 0137-706X.

Act No. 111/1998 Coll., On Higher Education Institutions and on Amendments to Other Acts (Higher Education Act). Zákon č. 111/1998 Sb., o vysokých školách a o změně a doplnění dalších zákonů (zákon o vysokých školách). (online) Dostupné z: http://www.msmt.cz/vzdelavani/vysoke-skolstvi/legislativa

\section{Acknowledgment}

This paper was supported by Charles University PROGRES Q17 - Teacher training and teaching profession in the context of science and research. 